\title{
A new diagnosis of the genus Delectona (Porifera, Demospongiae), with a description of a new species from the Alboran Sea (western Mediterranean)
}

\author{
D. Rosell \\ Centre d'Estudis Avançats de Blanes; Camí de Sta. Bàrbara, s/n. 17300-Blanes, Girona, \\ Spain
}

\begin{abstract}
A redescription of the genus Delectona is provided, based on information gained by the finding of a new species, $D$. alboransis, from the Alboran Sea (southwestern Mediterranean Sea). Up to now, this genus contained only one species: Delectona higgini, from the Indian Ocean, which has not been recorded since 1880 . The presence of megascleres in the new species and the different ranges of amphiaster lengths of the two species are the main features allowing a differentiation. In addition, the excavating capability of sponges of this genus is questioned, following the observations on the external morphology of $D$. alboransis. Our results support the hypothesis of other authors that some areas of the circalittoral level of the Alboran Sea may represent a redoubt of relict species with Indo-Pacific affinities.
\end{abstract}

\section{INTRODUCTION}

The genus Delectona was erected by Laubenfels (1936) for the excavating species Alectona higgini, described by Carter (1880) from the Indian Ocean. Laubenfels (1936) maintained the genus Delectona within the Clionidae. Latterly, Thomas (1972) mentioned the species in his paper on excavating sponges from the Indian Ocean, but he did not report any new record. Thus, the genus was up to the present known by only one specimen of the single species.

The Island of Alboran is situated in a Mediterranean basin under the influence of Atlantic and Mediterranean water masses (Lacombe, 1971; Lanoix, 1974). The facies of Corallium rubrum surveyed, between $70-120 \mathrm{~m}$ depth, is bathed by a particular water mass resulting from the interface between the Atlantic and Mediterranean waters. The peculiar salinity and temperature of this layer along with the rare vertical movement of its limits (Maldonado, 1992; Maldonado \& Uriz, 1995) seem to have maintained suitable environmental conditions that allow the survival of rare genera and/or species. These species are absent from both the Mediterranean and the near Atlantic, and show some affinities with representatives from the Indian Ocean. They are often claimed to be Tethy's relicts (Maldonado \& Benito, 1991; Boury-Esnault et al., 1992).

Sponges found living inside corals or any kind of limestone substrates have usually been considered capable of excavating calcareous substrates. In consequence, they were placed in the Clionidae because one of the main characteristics of this family is the ex- 


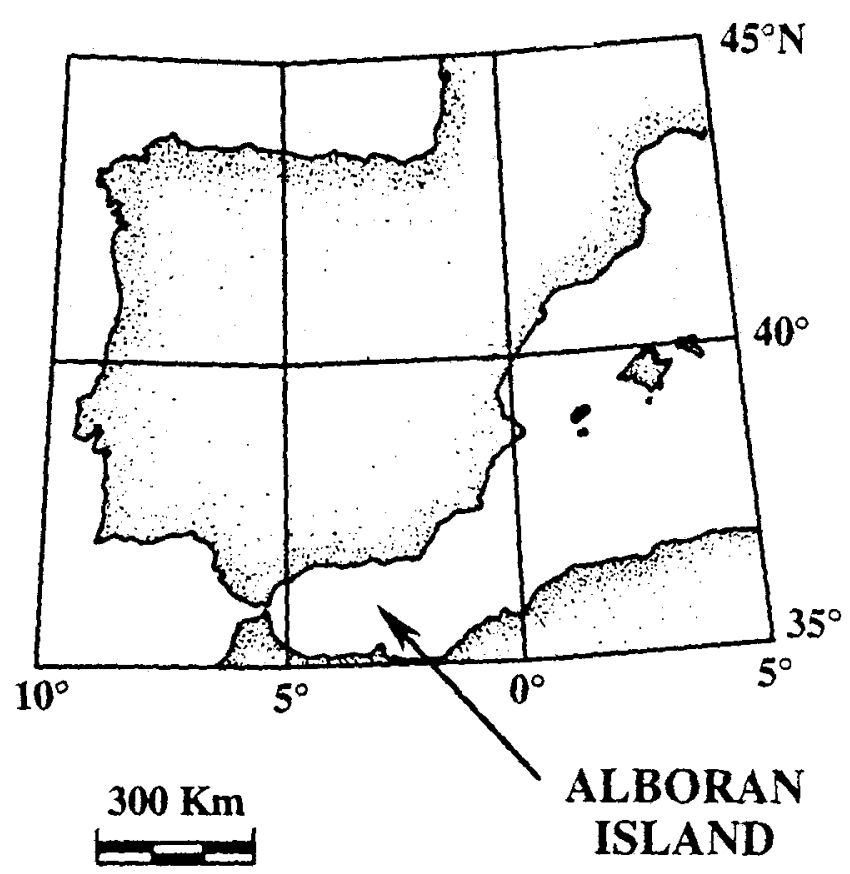

Fig. 1. Location of the sampling area

cavating ability of its members. At present, it has been largely demonstrated that other families, even from orders different from Hadromerida, include excavating sponges (Rützler, 1971; Hofman \& Kielman, 1992). On the other hand, the assumed excavating ability of some endolithic species has been questioned. This is the case of species, at present within the families Fipipolasidae, Samidae, Clathridae, Halichondriidae and Pachastrellidae, which were described either as excavating sponges or as merely encrusting forms living in previously existing cavities. Some of these, such as Samus anonyma Gray and Dercitus plicatus (Schmidt), were even described as being associated with species of Cliona (Annandale, 1915; Pulitzer-Finali, 1983; Carballo, 1994).

The genus Delectona is here redescribed on the basis of the information provided by the new species from the Alboran Sea. A description of this new species along with a discussion on its excavating ability are also presented.

\section{MATERIAL AND METHODS}

One specimen inhabiting cavities in branches of Corallium rubrum was collected during a research project on red coral fisheries undertaken by the Spanish Institute of Oceanography in 1984 . Samples were taken by dredge on a corallineous bottom nearby the Alboran Island (Fig. 1), located between $35^{\circ} 54^{\prime}-35^{\circ} 52^{\prime} \mathrm{N}$ and $3^{\circ} 09^{\prime}-3^{\circ} 05^{\prime} \mathrm{W}$ at depths of $70-120 \mathrm{~m}$.

Pieces of coral were fixed in $10 \%$ formaldehyde in seawater, then rinsed and preserved in $70 \%$ alcohol. Preparations of spicules and skeletons for light microscopy follow 
standard practice (Rützler, 1978). Preparation of spicules for scanning electron microscopy was performed by boiling in $\mathrm{H}_{2} \mathrm{NO}_{3}$, followed by dilution in alcohol, evaporation and metallization with gold-palladium before observation. Micrographs were obtained using a Hitachi scanning electron microscope.

Measures provided in the species description are ranges of length per width. Means, in brackets, are omitted when less than five measurements were made.

Different fragments of the holotype of Delectona alboransis are deposited in the collection of the Museo Nacional de Ciencias Naturales of Madrid (MNCNM) and in the collection of the Centre d'Estudis Avançats de Blanes (CEAB).

\section{RESULTS}

Family incertae sedis

Genus Delectona Laubenfels, 1936

Delectona Laubenfels, 1936. Pap. Tortugas Lab., 30 (467) : 156.

New diagnosis: Genus characterized by subtylostyles or styles and oxeas as megascleres and, as microscleres, spined toxiform microxeas, nodular-spined microstrongyles, spined amphiasters and spherasters. Spongin is present. Skeleton confused, occasionally arranged in tracts. Endolithic habit.

The type species is: $D$. higgini (Carter).

Two species are included within this genus: D. higgini (Carter) and D. alboransis new species.

\section{Delectona alboransis n. sp.}

Type specimens:

Hol ot y p e: One fragment and four slides (CEAB DEM-32).

$\mathrm{P}$ a r a t y p e: One fragment (MNCNM, 1.01/173).

E t y molog y: The specific epithet refers to the type locality, the Alboran Island.

External morphology: Massive species living inside coral galleries, but not attached to the cavity walls (Fig. 4 B). Smooth conulose surface with grooves (observed after fixation in alcohol) (Fig. 4 C). There is an oval orifice near some conules (Fig. 4 D), possibly related to the aquiferous system. Fleshy choanosome with wide canals (Fig. 4 B). Sponge easy to detach and friable. Colour whitish in alcohol and yellowish when dried.

Skeletal elements (Figs 2, 3,4 A; Table 1):

- Subtylostyles : $345-355 \times 10-27 \mu \mathrm{m}$. Shaft thicker near the sharp end and slightly centrally bent. Subterminal tyle slightly apparent. Smooth or wrinkled, sharp pointed end.

- O x e a s : $350-533 \times 2-3 \mu \mathrm{m}$, fusiform, irregularly flexuous at different points.

-Spined toxif or m microxeas (or reduced spined oxyasters): Thin and acerate faintly microspined shaft, of $72-111(98) \times \leq 1 \mu \mathrm{m}$, with a central enlargement or swelling. Actines are curved towards different directions, occasionally giving rise to toxoid forms.

- Nodular-spined microstrongyles : $22-64(42) \times 7-11(9) \mu \mathrm{m}$, subcylindrical, sometimes slightly curved, round at the ends, divided irregularly throughout the 

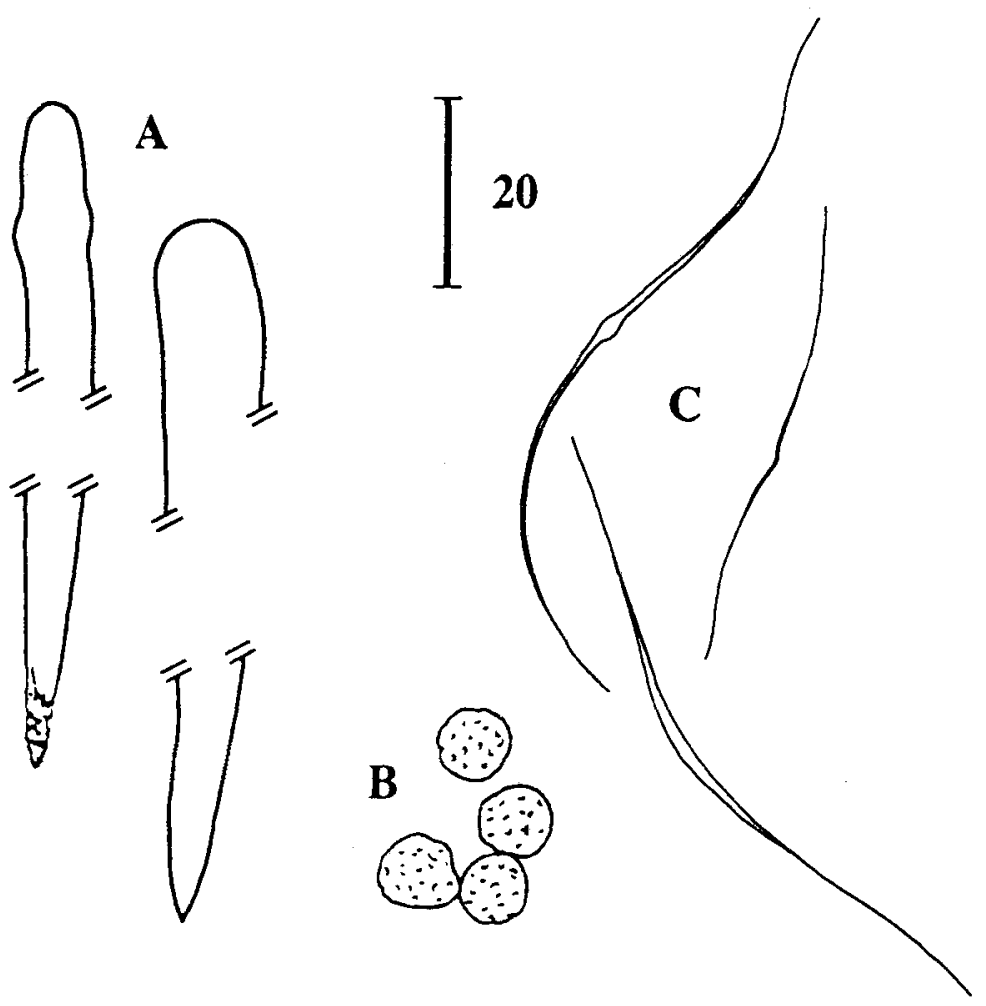

Fig. 2. Delectona alboransis. A: Subtylostyles. B: Spherasters. C: Microxeas. (Scale units in $\mu \mathrm{m}$ )

body into a number of annular depressions and inflations. Inflations are microspined, and very variable in form and length. The entire spicule, especially the spined nodules, seem to have formed in successive steps, as different layers can be distinguished (Fig. 3 D).

- A m phia ster s: Straight shaft, 34-45(37) $\mu \mathrm{m}$ in length, with two whorls of actines towards the centre with three or more faintly capitate actines in each whorl. Actines equal in length to the distance between the points of radiation and the end of the shaft on each side; all parts of the spicule about the same thinness, all microspined and all ending in an enlargement. Diameter of the actines is $0.5-1(0.7) \mu \mathrm{m}$.

- S p her a sters: Rough or spined, 10-15(12) $\mu \mathrm{m}$, with a high uniformity in size.

Skele to n: Spherasters almost exclusively in gemmules. They seem wrapped in spongin. The remaining skeletal elements confusedly arranged in the choanosome. The abundant nodular-spined microstrongyles and microxeas sometimes appear to be enveloped by spongin, and more or less arranged in tracts or fibres. The nodular-spined microstrongyles are also found concentrated at the top of the conules. Amphiasters quite conspicuous. Subtylostyles and large oxeas less frequent.

B i ology: This species inhabits branches of Corallium rubrum. The largest occupied cavity measured $12 \times 6 \mathrm{~mm}$. Nine asexual reproductive elements, possibly gemmules, have been observed in a small area of choanosome of $2 \mathrm{~mm}^{2}$. They are covered by a crust of spherasters and measure 195-275(224) $\times 266-329(292) \mu \mathrm{m}$. 


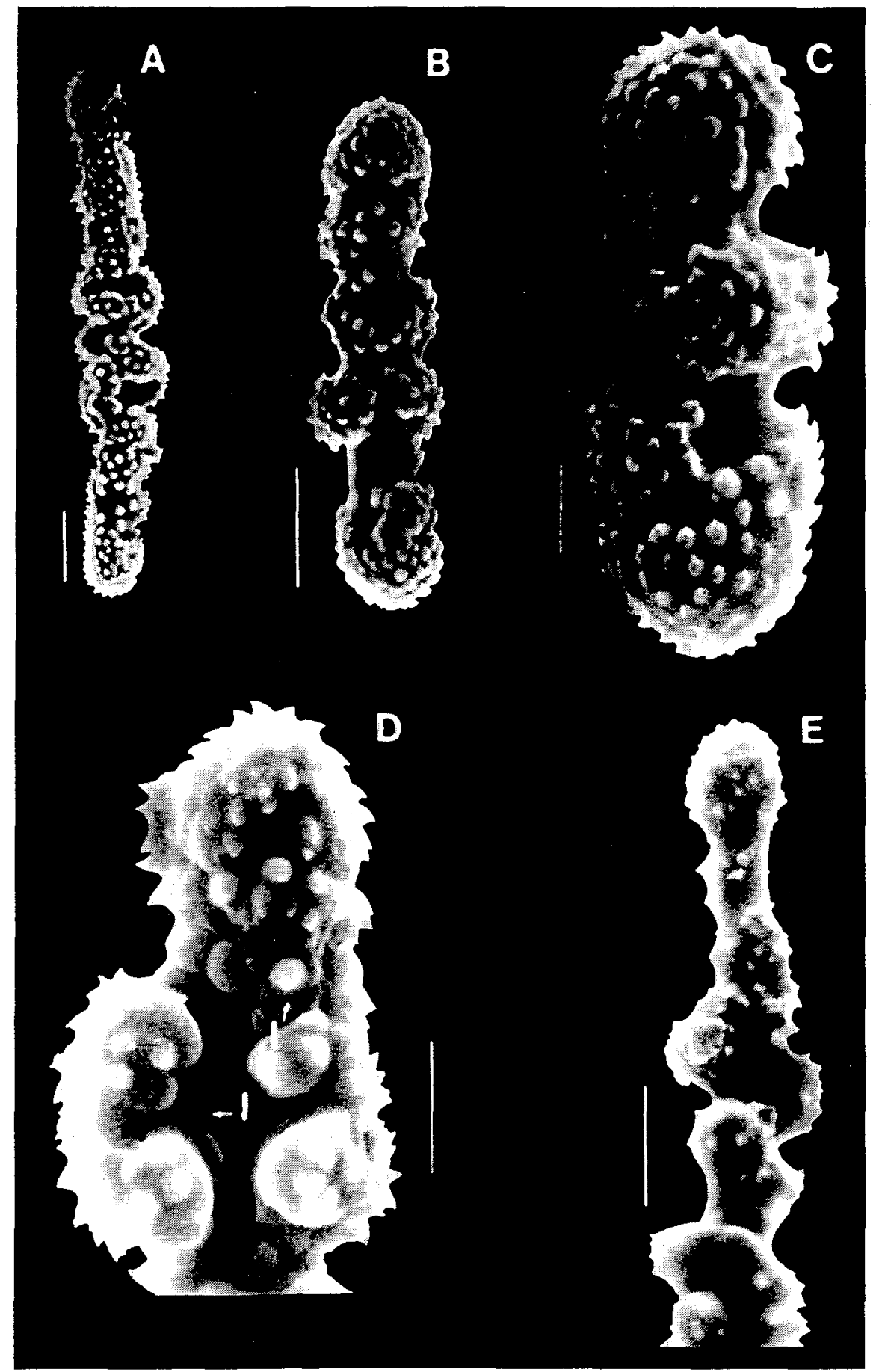

Fig. 3. Delectona alboransis. A, B, C: Nodular-spined microstrongyles (Scale bars: $10 \mu \mathrm{m}$ in A and B; $5 \mu \mathrm{m}$ in C). D: Detail of a nodular-spined microstrongyle in which layers of silica are visible (Scale bar: $5 \mu \mathrm{m}$ ); l: layers of silica. E: Young microstrongyle (Scale bar: $5 \mu \mathrm{m}$ ) (SEM) 

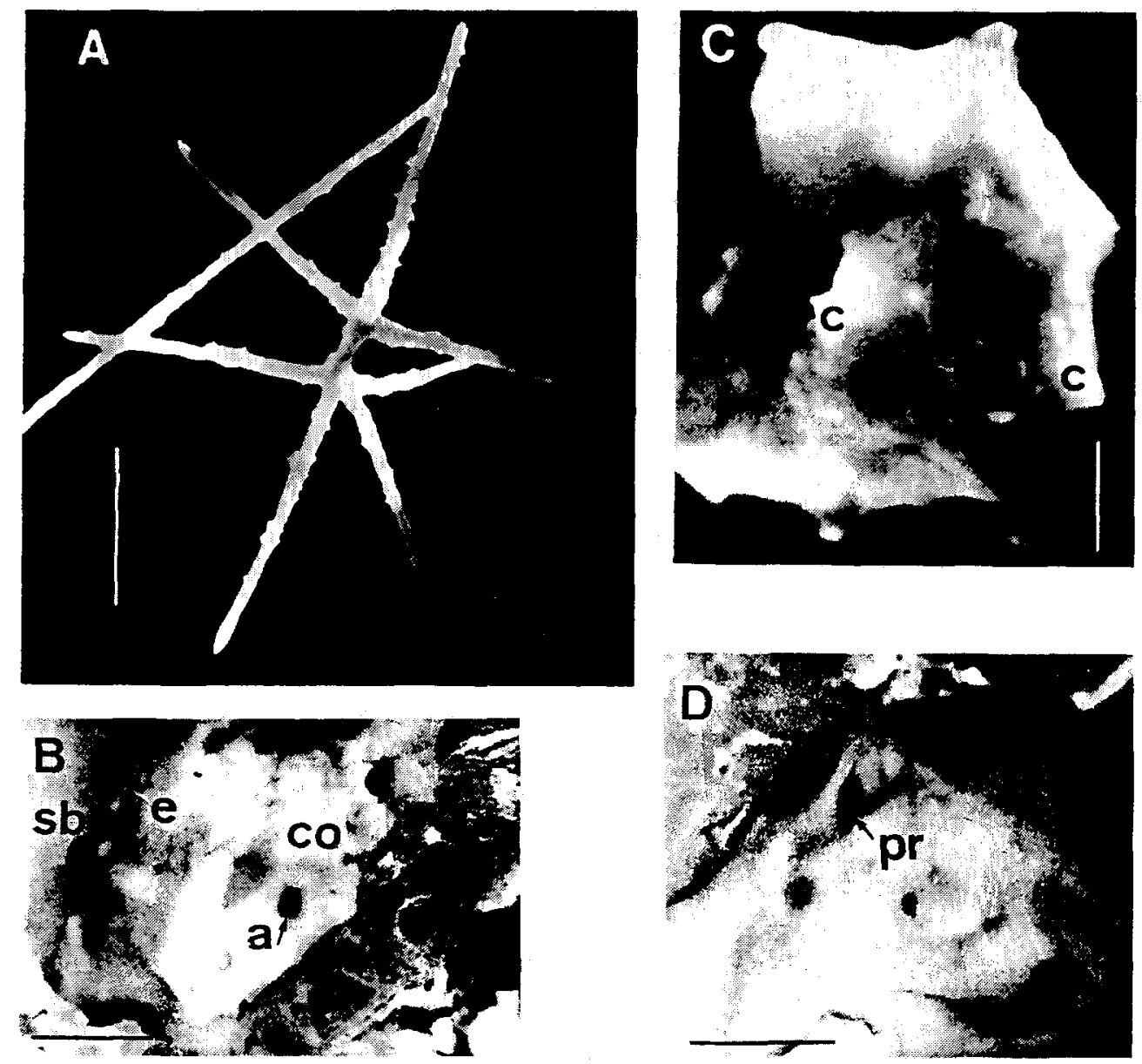

Fig. 4. Delectona alboransis. A: Amphiaster (Scale bar: 10 um) (SEM). B: Fleshy choanosome (Scale bar: $2 \mathrm{~mm}$ ) (LM). C: Massive specimen from one cavity (Scale bar: $1 \mathrm{~mm}$ ) (LM). D: Detail of the ectosomal orifice (Scale bar: $2 \mathrm{~mm}$ ) (LM). a: aquiferous canals, c: conule, co: choanosome,

e: ectosome, g: grooves, pr: orifice, sb: substratum

\section{DISCUSSION}

The genus Delectona was described by Laubenfels (1936) as having: "rhabds frequently subdivided by spined or verrucose subspheric inflations as unique spicular type". Nevertheless, he missed two of the spicular types previously described by Carter (1880) and later confirmed by Thomas (1972): the thin toxiform oxeas and a kind of streptaster with eight or more capitate rays. Not one of them observed the megasclere types or the spherasters. Spherasters seem to be restricted to the gemmules, which could explain why they might have easily remained unnoticed. We consider that the megascleres found are 
Table 1. Delectona higgini and Delectona alboransis sp. nov. Measures of the different spicular types. - Measures from Carter (1880). Values in brackets are means

\begin{tabular}{|lcc|}
\hline & D. higgini $\left({ }^{*}\right)$ & D. alboransis \\
\hline Spicule types $(\mu \mathrm{m})$ & & \\
Subtylostyles & - & $345-355 \times 10-27$ \\
Oxeas & 51 & $350-533 \times 2-3$ \\
Acanthoxeas & $21-85 \times 6-11$ & $72-111(98) \times \leq 1$ \\
Nodulose microst. & $5 \times 4 ?$ & $22-64(42) \times 7-11(9)$ \\
Amphiasters & - & $34-45(37)$ \\
Actines & $?$ & $0.5-1(0.7)$ \\
Spherasters & Indian Ocean & $10-15(12)$ \\
De p th $(\mathrm{m})$ & & $70-120$ \\
Loc a li ty & & Mediterranean Sea \\
\hline
\end{tabular}

not foreign spicules because of: (1) the massive morphology of our specimen, despite the fact that it inhabits a coral cavity; (2) its clean surface (Fig. 4 C, D) and (3) the fact that megascleres appear imbedded in the sponge tissue. Affinities between Delectona and Thoosa were already suggested by Laubenfels (1936). Now, the evidence of an occasional presence of subtylostyles, oxeas and euasters (sterrasters in Thoosa and spherasters in Delectona) in both genera clearly reinforces their systematic proximity.

The specimen from Alboran certainly belongs to the genus Delectona. The peculiar form of the nodular acanthorhabds leaves no doubt as to this. It should be pointed out, however, that this spicular type, viewed through a light microscope, closely resembles the calcareous spicules of some cnidarians. Laubenfels (1936) even doubted that this spicule was really of sponge origin. The irregular shape and surface of the spicule resemble desmoid spicules more than any other spicule type. This fact, together with the presence of euasters, separates definitively Delectona from the Clionidae and possibly from the Hadromerida. However, further studies in this sense will be necessary to highlight the uncertain systematic position of the genus.

Delectona higgini differs from $D$. alboransis in lacking, instead of having, megascleres and in the different ranges of amphiaster measures, allowing us to consider the specimen from the Alboran Sea as a new species. The habitat of both species is also different. $D$. higgini was found inhabiting only calcareous algae (its largest occupied cavity was about $30 \mathrm{~mm}$ in diameter) (Carter, 1880), whereas $D$. alboransis inhabits coral branches.

Although $D$. alboransis inhabits a calcareous substrate, no evidence of a true excavating activity can be demonstrated. Up to now, all excavating sponges had a pitted surface of the choanosome that was directly in contact with the substrate, the pits being the marks of the removed calcareous chips (author, pers, observ.). This pattern results from the close link between sponge and substrate when the excavating activity takes place. The presence of a pitted surface has not been observed in $D$. alboransis. After fixation, this sponge appears to be completely detached from the substrate, the surface which was in contact with the substrate being smooth. Moreover, no trace of calcareous fragments morphologically comparable to sponge-excavated chips has been observed. Thus, the 
its excavating ability. Therefore, even though it is not the main subject of this paper, we think that the excavating ability of $D$. higgini should also be questioned until its type material is examined.

The possibility of considering the Mediterranean Delectona as a possible remnant of Tethyan fauna should be taken into account, as no other previous record of species of this genus, despite the existence of the type species from the Indian Ocean, has been found. This hypothesis is supported by the findings of other authors on the bottoms of the Alboran Sea (Crambe tuberosa Maldonado \& Benito and Discorhabdella hindei BouryEsnault, Pansini \& Uriz) and, also, by the distinctive faunistic composition of the circalittoral level (sensu Pérès \& Picard, 1964) that lacks affinity with the close Atlantic and Mediterranean areas (Maldonado \& Uriz, 1995).

Acknowledgements. I am indebted to J. M. Fortuño for technical assistance in producing the scanning electron micrographs, to $\mathrm{M}$. Maldonado for providing the studied material, to D. Martin for his inestimable help in drawing the figures and for his comments, and to M. J. Uriz for her useful scientific criticism.

\section{LITERATURE CITED}

Annandale, N., 1915. Indian boring sponges of the family Clionidae.- Rec. Indian Mus. 11, 1-24.

Boury-Esnault, N., Pansini, M. \& Uriz, M. J., 1992. A new Discorhabdella (Porifera, Demospongiae), a new Tethyan relict of pre-Messinian biota?- J. nat. Hist. 26, 1-7.

Carballo, J. L., 1994. Taxonomía, zoogeografía y autoecología de los poríferos del Estrecho de Gibraltar. Ph. D. Thesis, Univ. de Sevilla, 334 pp.

Carter, H. J., 1880. Report on specimens dredged up from the Gulf of Manaar and presented to the Liverpool Free Museum by Capt.W. H. Cawne Warren.- Ann. Mag. nat. Hist. 6, 35-61.

Hofman, C. C. \& Kielman, M., 1992. The excavating sponges of the Santa Marta area, Colombia, with description of a new species.- Bijdr. Dierk. 61, 205-217

Lacombe, H., 1971. Le Détroit de Gibraltar, océanographie physique.- Notes Mém. Serv. Mines Carte géol. Maroc 22, 111-146.

Lanoix, F., 1974. Projet Alboran, étude hydrologique et dynamique de la mer d'Alboran.- Rapp. tech. Org. Traité de l'Atlantique du Nord 66, 1-70.

Laubenfels, M. W. de, 1936. A discussion of the sponge fauna of the Dry Tortugas in particular and the West Indias in general, with material for a revision of the families and orders of the Porifera.Pap. Tortugas Lab. 30, 1-225.

Maidonado, M., 1992. Demosponges of the red coral bottoms from the Alboran Sea,- J. nat Hist. 26, 1131-1161.

Maldonado, M. \& Benito, J., 1991. Crambe tuberosa n. sp. (Demospongiae, Poecilosclerida): a new Mediterranean poecilosclerid with lithistid affinities.- Cah. Biol. mar. 32, 323-332.

Maldonado, M. \& Uriz, M. J., 1995. Biotic affinities in a transitional zone between the Atlantic and the Mediterranean: a biogeographical approach based on sponges.- J. Biogeogr. 22, 89-110.

Pérès, J. M. \& Picard, J., 1964. Nouveau manuel de bionomie benthique de la Mer Méditerranée.Recl Trav. Stn mar. Endoume 31, 1-137.

Pulitzer-Finali, G., 1983. A collection of Mediterranean Demospongiae (Porifera) with, in appendix, a list of the Demospongiae hitherto recorded from the Mediterranean Sea.- Annali Mus. Civ. Stor. nat. Giaccomo Doria 84, 445-621.

Rützler, K., 1971. Bredin-Archbold-Smithsonian biological survey of Dominica: Burrowing sponges, Genus Siphonodictyon Bergquist, from the Caribbean.- Smithson. Contr. Zool. 77, 1-37.

Rützler, K., 1978. Sponges in coral reefs. In: Geological evolution of the Mediterranean basin. Ed. by D. R. Stoddart \& R. E. Johannes. Springer, Berlin, 347-354.

Thomas, P. A., 1972. Boring sponges of the reefs of Gulf of Mannar and Palk Bay. In: First symposium on corals and coral reefs. Ed. by C. Mukundan \& C. S. G. Pillai. Marine Biological Association of India, Manddapam Camp, 333-362. 